\title{
CORRIGENDA
}

Studies on the digestibility and utilization of the nitrogen of irradiated rumen bacteria by rats

By V. C. MASON AND R. PALMER

J. agric. Sci. 76, 567-572

The authors regret that the column in Table 3 on p. 570 headed:

mg DAPA $/ 100 \mathrm{~g}$ faecal nitrogen (mean \pm s.E.)

Should read:

g DAPA $/ 100 \mathrm{~g}$ faecal nitrogen (mean \pm s.E.)

The digestion of bacterial mucopeptide constituents in the sheep

I. The metabolism of 2,6-diaminopimelic acid

BY V. C. MASON AND F. WHITE

J. agric. Sci. 77, 91-98

The labelling of the abscissa in Figs 4 and 5 should be transposed.

The effect of urea on the utilization of ground, pelleted roughage by penned sheep

III. Mineral supplements

By J. B. COOMBE, K. R. CHRISTIAN AND M. D. HOLGATE

J. agric. Sci. 77, 159-174

The authors regret that all serum urea values in this paper should be multiplied by $0 \cdot 4$. 


\section{Grassland Ecology}

\section{R. W. SPEDDING}

This book has been written for all who are interested in forming a coherent view of whole grassland ecosystems; of the animals that live in, on, or under the plant populations as well as the plants themselves. Agriculturally useful plants and animals are emphasized because of the great importance of grassland in world food production. An understanding of whole systems is required, not only to manipulate them safely and successfully for our purposes, but also in order to decide on the best use of resources.

32 text-figures $\mathfrak{f 2}$

\section{OXFORD}

UNIVERSITY PRESS

\section{EXPERIMENTAL AGRIGULTURE \\ VOLUME 7 NUMBER 3 JULY 1971 CONTENTS}

A. Bolton: Response of Maize Varieties in Tanzania to Different Plant Populations and Fertilizer Levels

P. A. HuXley and J. M. WALler: A Simple Wetness Recorder

A. Marani and A. Amirav: Effects of Soil Moisture Stress on Two Varieties of Upland Cotton in Israel. I. The Coastal Plain Region

D. Shimshi and A. Marani: Effects of Soil Moisture Stress on Two Varieties of Upland Cotton in Israel. II. The Northern Negev Region

H. K. PANDE and B. N. MitTra: Effects of Depth of Submergence, Fertilization and Cultivation on Water Requirement and Yield on Rice

T. P. Arraham, A. Hoobakht and Parvin Aryan Nejad: Statistical Studies of Experimental Techniques with the Apple Crop in Iran

A. WILD: The Potassium Status of Soils in the Savanna Zone of Nigeria

Book Review:

J. K. R. Gasser: Rice Fertilization

$£ 2.00$ net $\left(\$ 6.5^{\circ}\right.$ in U.S.A.). Annual subscription $£ 7$ net (\$23.00 in U.S.A.) for four issues

CAMBRIDGE UNIVERSITY PRESS 


\section{THE JOURNAL OF AGRICULTURAL SCIENCE}

\section{CONTENTS}

\section{Vol. 77 Part 2 October 1971}

Bunting, E. S. Plant density and yield of shoot dry material in maize in England. (With 4 text-figures)

Eagles, C. F. and Williams, D. H. Competition between natural populations of Dactylis glomerata. (With 2 text-figures)

OWEN, J. B., MILler, E. L. and Bridge, P. S. Complete diets given ad libitum to dairy cows: the effect of straw content and of cubing the diet

MALOIY, G. M. O. and TAYLOR, C. R. Water requirements of African goats and haired-sheep. (With 3 text-figures)

Halliday, R. Total protein and immunoglobulin concentrations in sera from 2-day-old Finnish Landrace $\times$ Dorset Horn lambs. (With 1 text-figure)

Toynbeb-Clarke, Gillian. Pollination studies with highly-inbred lines of winter beans (Vicia faba L.)

Agbool A, A. A. and FAYem, A. A. Preliminary trials on the intercropping of maize with different tropical legumes in Western Nigeria. (With 1 text-figure)

CONNIFFE, D. Treatment comparisons in grazing trials using the animal as experimental unit. (With 1 text-figure) .

IsHAG, H. M. Weed control in irrigated groundnuts (Arachis hypogaea L.) in the Sudan Gezira. (With 2 text-figures)

EDDowes, M. The effect of application rate of chemical herbicides on weed control and yield in early potatoes

EDDowes, M. Weed control in sugar beet with single and split applications of herbicides . .

BolToN, J. and SLOPE, D. B. Effects of magnesium on cereals, potatoes and leys grown on the 'continuous cereals' site at Woburn. (With 3 text-figures)

Davies, P. J., Johnston, R. G. and Ross, D. B. The influence of energy intake on plasma levels of glucose, non-esterified fatty acids and acetone in the pregnant ewe . .

Johnson, K. G. Body temperature lability in sheep and goats during short-term exposures to heat and cold. (With 3 text-figures) .

DAviEs, Alison. Growth rates and crop morphology in vernalized and non-vernalized swards of perennial ryegrass in spring. (With 8 text-figures)

RHODEs, I. The relationship between productivity and some components of canopy structure in ryegrass (Lolium spp.). II. Yield, canopy structure and light interception. (With 2 plates and 6 text-figures)

O'NenLL, S. J. B., BALNAVE, D. and JACKson, N. The influence of feathering and environmental temperature on the heat production and efficiency of utilization of metabolizable energy by the mature cockerel. (With 2 text-figures)

Price, M. A. and Yeates, N. T. M. Infertile bulls versus steers. I. The influence of level of nutrition on relative growth rate. (With 2 text-figures)

PAGE

Price, M. A. and Yeates, N. T. M. Infertile bulls versus steers. II. Feed conversion efficiency and the effects of a high fat diet

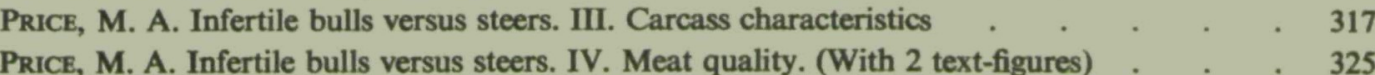

STEINBACH, J. Effects of season and breed on sow performance in the seasonal-equatorial climate of Southern Nigeria. (With 2 text-figures)

HEYNS, H. The relationship between various blood constituents of young Afrikaner bulls .

Allen, E. J., Morgan, D. G. and Ridgman, W. J. A physiological analysis of the growth of oilseed rape. (With 1 text-figure)

Robinson, J. J. and GiLL, J. C. A note on observations on the effect of photostimulation and hormone treatment on the oestrous activity and lambing performance of North Country Cheviot ewes

C Cambridge University Press, 1971

SUBSCRIPTIONS. Two volumes of three parts are published annually. The subscription price is $£ 6.00$ net (U.S.A. \$19.50) per volume (post free); single parts are available at $£ 2.60$ net (U.S.A. (\$8.00) plus postage. Orders or enquiries may be sent to any bookseller or subscription agent, or to Cambridge University Press, P.O. Box 92, London N.W.1. (U.S.A. and Canada, Cambridge University Press American Branch, 32 East 57th Street, New York, N.Y. 10022, U.S.A.) 